\title{
TRANSFUSION PRACTICE OF PACKED RED BLOOD CELLS TO LOW BIRTH WEIGHT PRETERM NEONATES IN A LEVEL-3 NEONATAL UNIT
}

\author{
A.E. Abdelhamid ${ }^{1}$, N. Murray ${ }^{2}$ \\ ${ }^{1}$ University College of London, ${ }^{2}$ Neonatal Unit, Homerton University Hospital, London, UK
}

Background: $65 \%$ of low-birth-weight (LBW) infants admitted to the neonatal intensive care unit (NICU) receive multiple transfusions mainly of packed red blood cells (PRBCs), supposedly steered by evidencebased guidelines. In addition to the absolute haemoglobin $(\mathrm{Hb})$ level, transfusion depends on such factors as oxygen requirements, ventilation, and erythrocyte regenerative activity.

Aim: Audit transfusion practice of PRBCs to infants with birth weight of $\leq 1500$ grams in the Homerton Hospital NICU.

Method: Retrospective analysis of the transfusion practice of RBCs in infants with birth weight of $\leq 1500$ grams.

Results: The higher incidence of transfusion events was in the 27-to-30 weeks' group. Transfusions were given to $47 \%$ of babies on mechanical ventilation, $22.5 \%$ on nCPAP, $12.5 \%$ self-ventilating in $\mathrm{O}_{2}\left(\mathrm{SVIO}_{2}\right)$, and $18 \%$ in air.The median values of $\mathrm{Hb}$ were higher in the MV group (128 [practice] vs 120 [guidelines] $\mathrm{g} / \mathrm{l}$ ), versus 103,94 , and $79 \mathrm{~g} / \mathrm{l}$ in each of the other groups respectively. The median $\mathrm{FiO}_{2}$ trigger for transfusing babies on MV was $30 \%$, but $27 \%$ for those on nCPAP, and $35 \%$ for those who are spontaneously breathing in $\mathrm{O}_{2} .43 \%$ of babies were transfused beyond the neonatal period, followed by those transfused during the first week (18\%). Numbers of transfusions per baby ranged from one in $\sim 29 \%$ ), to $>11$ in $\sim 10 \%$ of patients.

Conclusions: We are still transfusing at higher $\mathrm{Hb}$, ventilator support, and $\mathrm{FiO}_{2}$ thresholds stated by the guidelines. Clinical approach taking "symptoms" and reticulocyte count into consideration is not usually followed when deciding for PRBCs transfusions. 